\title{
Effect of dietary supplementation with $\beta$-casein A1 or A2 on markers of disease development in individuals at high risk of cardiovascular disease
}

\author{
Jaye Chin-Dusting*, Jane Shennan, Emma Jones, Carolyn Williams, Bronwyn Kingwell and Anthony Dart \\ Alfred and Baker Medical Unit, Wynn Domain, Baker Heart Research Institute and Alfred Hospital, Commercial Road, Melbourne, \\ Victoria 3004, Australia
}

(Received 1 April 2005 - Revised 8 August 2005 - Accepted 11 August 2005)

\begin{abstract}
The present study is the first to examine the hypothesis that dietary supplementation with $\beta$-casein A1 promotes an increased risk relative to supplementation with $\beta$-casein A2 in patients traditionally at high risk of developing CVD. The study was conducted in fifteen asymptomatic participants (six male; nine female) at high risk of developing CVD. A double-blind cross-over study design was used with a total duration of 24 weeks. Dietary intervention was a daily supplementation $(25 \mathrm{~g})$ of either casein A1 or A2 (for 12 weeks each). Surrogate measures of cardioprotection studied included the examination of vascular (endothelium and arterial) function, resting blood pressure, plasma lipids and biochemical markers of inflammation. Total plasma cholesterol levels were significantly lower following 12 weeks of both casein A1 and A2 interventions but the decrease was not different between intervention. Plasma insulin, homocysteine, C-reactive protein, fibrinogen, protein C and S and von Willebrand factor levels were not different between the two casein supplements. Endothelium function, measured as a vascular response using venous occlusion plethysmography to intra-aterial infusions of the endothelium-dependent agonist acetylcholine, were not different between the two casein interventions. Similarly, neither blood pressure nor measures of large artery stiffness were affected by differing the casein variant. We therefore conclude that there is no evidence from the present study that supplementation with casein A1 has any cardiovascular health disadvantage over consumption of casein A2.
\end{abstract}

Milk protein: Casein: Man: Dietary supplementation: Cardiovascular risk

There are many well-identified risk factors for CVD including hypertension, hypercholesterolaemia, smoking and diabetes (Yusuf et al. 2004). From time to time, consumption of milk products has also been implicated (McLachlan, 2001; Laugesen \& Elliott, 2003), but any direct link between milk and vascular disease including death or symptoms from CHD has been difficult to define.

Bovine milk, the most common source of milk consumed in developed countries, contains six major proteins; four caseins that constitute approximately $80 \%$ of the protein composition, and two whey proteins. The caseins have been subdivided into four classes $\alpha_{\mathrm{s} 1}, \alpha_{\mathrm{s} 2}, \beta$ and $\kappa$, with $\alpha_{\mathrm{s} 1}$ and $\beta$-casein being the most abundant (Davies \& Law, 1980). While up to ten genetic variants of $\beta$-casein have been sequenced and identified, the majority of cows in Western nations, including the Holstein and Ayrshire breeds, produce milk rich in the $\beta$-casein A1 genetic variant (McLean et al. 1984). While a non-association has been reported between milk consumption per se and cardiovascular mortality (Ness et al. 2001), data pooled from several populations are suggestive of a strong correlation between consumption of $\beta$-casein A1 and IHD (McLachlan, 2001; Laugesen \& Elliott, 2003). To date, only one intervention study has been performed where high-fat-fed rabbits administered $\beta$-casein A1 demonstrated a greater atherogenic vascular profile than their counterparts fed A2 (Tailford et al. 2003). A1-fed animals had higher plasma cholesterol levels as well as a greater percentage coverage of fatty streaks in their aorta.

The present study is the first to examine the hypothesis that dietary supplementation of $\beta$-casein A1 will promote an increased relative risk in patients at high risk of developing CVD when compared with dietary administration of casein A2. Surrogate measures of cardioprotection have been studied, including the examination of vascular function including endothelium function (an assessment of the dynamic influence of the endothelium, i.e. the single cell inner lining of blood vessels) and arterial function (an assessment of arterial biomechanical properties), resting blood pressure, plasma lipids and biochemical markers of inflammation. The assessment of endothelium function is based on the commonly accepted hypothesis that diminished NO bioavailability is a hallmark of early atherosclerosis and has valuable predictive value for future cardiovascular events (Spieker et al. 2002), while elevated arterial stiffness has been demonstrated to predict impaired survival in hypertensive patients (Laurent et al. 2003). Plasma biochemical markers associated with CVD include hyperinsulinaemia (El-Atat et al. 2004), hyperhomocysteinaemia (Lentz \& Haynes, 2004) and C-reactive protein (Bassuk et al. 2004). 


\section{Materials and methods}

\section{Participants}

The study was a double-blind cross-over study, without washout, conducted in fifteen asymptomatic participants (six male; nine female) at high risk of developing CVD. These were defined as those who had two or more of the following recognised cardiovascular risk indices: current smokers, BMI $>25 \mathrm{~kg} / \mathrm{m}^{2}$, plasma cholesterol $>6.0 \mathrm{mmol} / \mathrm{l}$, systolic blood pressure $>145 \mathrm{mmHg}$ and/or with a family history with one (or more) parent showing onset of CVD under the age of 60 years. Table 1 details the demographics of these patients. Exclusion criteria included past history of vascular disease including angina, myocardial infarction, transient cerebral ischaemia or other vascular diseases now quiescent, symptoms of macrovascular disease presenting in any form, known allergy to milk or milk products, concurrent chronic disease that requires medication with non-steroidal anti-inflammatory agents, steroids, or chemotherapy or assessment by the investigator or dietitian concluding that a given patient is unlikely to comply with the dietary requirements of the study. Table 2 details the habitual dairy intake of the subjects recruited at the time of study inclusion.

\section{Casein powder}

Dairy shakes containing $\beta$-casein A1 or A2 were provided by A2 Corporation Ltd (Auckland, New Zealand), who commissioned the preparation in two flavours, vanilla and chocolate, by Anadis Limited Research \& Development (Campbellfield, Australia). These were stable and stored at room temperature. Ingredients of the dairy shakes are listed in Table 3.

\section{Consumption}

Consumption consisted of a daily intake $(25 \mathrm{~g})$ of the dairy shake. This approximated two flat tablespoons $(15 \mathrm{ml}$; tablespoon measure provided) of the powder reconstituted in approximately $200 \mathrm{ml}$ water or fruit juice (not milk) in a shaker provided. This was shaken well and left to rest for 2 min to allow the texture and flavour to develop. Cold or hot water could be used; boiling water was not (as it degraded the protein). Further food flavourings could be used, for example, instant coffee added to the chocolate powder to give a mocha taste or raspberry topping or vanilla essence with the vanilla powder. Orange juice used to reconstitute the vanilla powder was a popular drink. Participants were advised that lesser volumes of water could be used to make a thicker product if desired, as long as $25 \mathrm{~g} / \mathrm{d}$ was consumed.

The amount of casein (A1 or A2) delivered approximated to $10 \mathrm{~g} / \mathrm{d}$. Based on Dairy Australia (2005) estimations that the annual milk consumption per capita is 100 litres, i.e. $270 \mathrm{ml} / \mathrm{d}$, that the amount of protein is $4 \mathrm{~g} / 100 \mathrm{ml}$ standard milk and that casein (mainly $\alpha_{\mathrm{s} 1}$ and $\beta$-casein) makes up approximately $80 \%$ total protein content in milk, the amount of $\beta$-casein delivered $(10 \mathrm{~g})$ is at least as much if not more than that consumed via a normal diet.

The study was of cross-over design, the total duration of which was 24 weeks; where each participant consumed first one casein variant (12 weeks) followed by the other (also 12 weeks). The Clinical Trials Service of the Pharmacy Department of the Alfred Hospital carried out the dispensing protocol, enabling a double-blind protocol to the initiated. Before commencement of the study each participant took part in a one-on-one consultation with a dietitian and was given instructions and advice on minimising milk intake from other sources during the entire study period. In general, all participants were advised to avoid milk of any description (including flavoured milk), custard and rice pudding; and that other dairy products, for example, yoghurt, sour cream, cream and ice cream (for example, to be reduced to once a fortnight) were to be consumed in moderation. Exceptions were made for cheese of all varieties (as the renneting and fermenting process is believed to alter casein structure; Menedez et al. 2000), butter and margarine, which contain mostly fat (rather than protein). More stringent dietary restrictions were not introduced in order to maximise patient recruitment and retention, as this was a long-term participant-demanding

Table 1. Study participant demographics*

\begin{tabular}{|c|c|c|c|c|c|c|c|}
\hline Patient identification no. & Sex & Age & Family history† & BMI $\left(\mathrm{kg} / \mathrm{m}^{2}\right)$ & Current smoker & Cholesterol (mmol/l) & Blood pressure $(\mathrm{mmHg})$ \\
\hline 1 & Female & 67 & Yesł & $31 \cdot 6 \ddagger$ & No & $5 \cdot 22$ & $135 / 71$ \\
\hline 2 & Female & 54 & Yesł & $26 \cdot 7$ & No & $7.02 \ddagger$ & $117 / 80$ \\
\hline 4 & Female & 61 & No & $22 \cdot 1$ & Yesł & $6.29 \ddagger$ & $139 / 89$ \\
\hline 5 & Male & 66 & Yesł & $30 \cdot 8 \ddagger$ & No & $6.52 \ddagger$ & 150/80‡ \\
\hline 6 & Male & 50 & Yesł & $30.4 \ddagger$ & No & 5.94 & $134 / 79$ \\
\hline 7 & Male & 49 & No & $27 \cdot 3^{\top}$ & Yesł & 4.96 & $152 / 99 \ddagger$ \\
\hline 9 & Male & 41 & Yesł & $21 \cdot 8$ & Yesł & $5 \cdot 33^{\top}$ & $126 / 82$ \\
\hline 10 & Male & 41 & No & $25 \cdot 6$ & Yesł & $6.94 \ddagger$ & $143 / 80$ \\
\hline 11 & Female & 65 & Yesł & 19.9 & No & $6.02 \ddagger$ & $128 / 63$ \\
\hline 12 & Female & 42 & Yesł & $26 \cdot 1$ & No & 4.43 & $129 / 67$ \\
\hline 13 & Female & 57 & Yesł & $20 \cdot 8$ & No & 5.63 & $114 / 70$ \\
\hline 14 & Female & 67 & Yesł & $21 \cdot 3$ & No & $6.05 \ddagger$ & $147 / 73 \ddagger$ \\
\hline 15 & Male & 32 & Yesł & 27.9 & No & 4.65 & $127 / 71$ \\
\hline
\end{tabular}

*Fifteen asymptomatic participants at high risk of developing CVD were recruited. These were defined as those who had two or more of the following recognised cardiovascular risk indices: current smokers, BMI $>25 \mathrm{~kg} / \mathrm{m}^{2}$, plasma cholesterol $>6.0 \mathrm{mmol} / \mathrm{l}$, systolic blood pressure $>145 \mathrm{mmHg}$ and/or with a family history with one (or more) parent showing onset of CVD under the age of 60 years. 
Table 2. Habitual dairy intake of study participants

(Mean values with their standard errors)

\begin{tabular}{|c|c|c|c|c|c|c|c|}
\hline \multirow[b]{2}{*}{ Food } & \multirow[b]{2}{*}{ Serving size } & \multicolumn{3}{|c|}{ Content per serving } & \multicolumn{3}{|c|}{ Servings per week } \\
\hline & & Fat (g) & $\mathrm{Ca}(\mathrm{mg})$ & Energy (kJ) & Range & Mean & SEM \\
\hline \multicolumn{8}{|l|}{ Milk } \\
\hline Whole & $250 \mathrm{ml}$ & 9.5 & 285 & 680 & 0 & 0 & 1.9 \\
\hline Reduced-fat & $250 \mathrm{ml}$ & 9.5 & 345 & 510 & $0-21$ & $2 \cdot 7$ & 0.9 \\
\hline Low-fat & $250 \mathrm{ml}$ & 0.5 & 300 & 500 & $0-10.5$ & 1.6 & 0 \\
\hline Skimmed & $250 \mathrm{ml}$ & 0.2 & 310 & 360 & 0 & 0 & \\
\hline \multicolumn{8}{|l|}{ Yoghurt } \\
\hline Plain & $200 \mathrm{~g}$ & $6 \cdot 8$ & 340 & 560 & $0-1$ & 0.2 & 0.1 \\
\hline Plain, low-fat & $200 \mathrm{~g}$ & 0.4 & 420 & 400 & $0-7$ & $0 \cdot 1$ & 0.6 \\
\hline Fruit & $200 \mathrm{~g}$ & $5 \cdot 6$ & 340 & 760 & $0-28$ & 2.5 & $2 \cdot 3$ \\
\hline Fruit, low-fat & $200 \mathrm{~g}$ & 0.4 & 360 & 600 & $0-7$ & $1 \cdot 2$ & 0.8 \\
\hline Fruche* & $200 \mathrm{~g}$ & 8 & 160 & 960 & $0-0.5$ & 0.06 & 0.04 \\
\hline Cheese & $35-50 \mathrm{~g}$ & $3-11.8$ & $40-380$ & $200-620$ & $1-16$ & $6 \cdot 4$ & 1.4 \\
\hline Ice cream, regular & $100 \mathrm{~g}$ & 5 & 120 & 805 & $0-3$ & 0.7 & $1 \cdot 3$ \\
\hline Soured cream, regular & $20 \mathrm{~g}$ & 3.5 & 30 & 160 & $0-1$ & 0.1 & 0.1 \\
\hline Cream, regular & $20 \mathrm{~g}$ & 8 & 15 & 300 & $0-2$ & 0.5 & 0.3 \\
\hline
\end{tabular}

${ }^{\star}$ Fromage frais-based dairy snack.

For details of subjects and procedures, see p. 137.

Table 3. Ingredients of the dairy shakes when casein delivered either with vanilla or cocoa flavour ${ }^{\star}$

\begin{tabular}{|c|c|c|c|c|c|}
\hline \multicolumn{3}{|c|}{ Vanilla flavour } & \multicolumn{3}{|c|}{ Chocolate flavour } \\
\hline Ingredients & $\%$ Weight & g & Ingredients & $\%$ Weight & $\mathrm{g}$ \\
\hline Casein $\mathrm{A} 1$ or $\mathrm{A} 2 \dagger$ & $41 \cdot 75$ & $20 \cdot 00$ & Casein $\mathrm{A} 1$ or $\mathrm{A} 2^{*}$ & $40 \cdot 49$ & $20 \cdot 00$ \\
\hline Fieldose17 & $20 \cdot 88$ & $10 \cdot 00$ & Fieldose17 & $20 \cdot 24$ & $10 \cdot 00$ \\
\hline Fructose & $16 \cdot 70$ & $8 \cdot 00$ & Fructose & $16 \cdot 19$ & 8.00 \\
\hline Dextrose & $16 \cdot 70$ & 8.00 & Dextrose & $16 \cdot 19$ & 8.00 \\
\hline Vegetable gum & 0.10 & 0.05 & Vegetable gum & 0.10 & 0.05 \\
\hline Vanilla flavour 4240 & $3 \cdot 13$ & 1.50 & Cocoa 250DP11 & 3.04 & 1.50 \\
\hline Cream flavour 05922 & 0.63 & 0.30 & Choc flavour 8649 & 3.04 & 1.50 \\
\hline \multirow[t]{2}{*}{ Sherex } & 0.10 & 0.05 & Cream flavour 05922 & 0.61 & 0.30 \\
\hline & & & Sherex & 0.10 & 0.05 \\
\hline Total & $100 \cdot 00$ & $47 \cdot 90$ & Total & $100 \cdot 00$ & $49 \cdot 40$ \\
\hline
\end{tabular}

${ }^{*}$ For details, see p. 137.

†Post-analysis by the suppliers of the dairy shakes indicated the purity of the casein A1 or A2 to be $>80 \%$.

study trial, as well as to achieve a realistic lifestyle approach. Subject compliance to the supplementation was determined by return of canisters.

The study was approved by the Alfred Hospital Institute Ethics committee, informed written consent was obtained from all participants, who were aware that they could withdraw from the study at any time of their choosing.

\section{Visits}

The study required five visits to the Alfred Hospital over the 24-week study period for each participant. Visits were at study weeks $0,6,12,18$ and 24 . At 0 weeks, eligibility for participation was confirmed, a medical history and physical examination was performed by a registered clinical practitioner and a separate consultation with a dietitian took place. Dispensing of dairy powder was arranged at the end of the visit. Determination of systemic arterial compliance, dietary adherence, blood samples and blood pressure were determined at all visits. Measurement of endothelium function by plethysmography was performed during weeks 12 and 24. Details of all these procedures are described later.

\section{Blood samples}

Fasting blood was taken and sent to the pathology department at the Alfred Hospital for analysis of total plasma cholesterol, HDL-cholesterol, LDL-cholesterol, triacylglycerol levels (all with Abbott Architect CI8200; Abbott Laboratories, Abbott Park, IL, USA), fibrinogen (quantitative determination by clotting method; STA Analyser, Diagnostica Stago, Asnieres, France), von Willebrand's factor (by ELISA), protein S (immunoturbidimetric assay by STA Analysers, Diagnostica Stago, Asnieres, France) and protein C (colorimetric assay by STA Analysers), homocysteine (fluorescence polarisation immunoassay; Abbott AXsym System; Abbott Laboratories), C-reactive protein (Latex particle enhanced immunoturbidimetric assay; Roche Diagnostics, Rotkreuz, Switzerland) and insulin (microparticle enzyme immunoassay; Abbott IMx Insulin Assay; Abbott Diagnostics Division, Wiesbeden, Germany) before commencing the study and at 6-week 
intervals, i.e. in the middle and end of each of the two phases of milk consumption.

\section{Blood pressure}

Supine blood pressure and heart rate were obtained after a 30 min rest using a Dinamap automatic blood pressure recorder placed on the upper arm, above the brachial artery (Critikon Inc., Tampa, FL, USA). The average of three consecutive readings (5 min apart) was calculated and used as the reading for that visit.

\section{Determination of endothelial function}

All participants were instructed to fast overnight before the day of study. On the day of study, where applicable, the dairy shake was not taken until after the study had completed. The study was performed in a quiet room maintained between 21 and $24^{\circ} \mathrm{C}$. The brachial artery of the non-dominant arm was cannulated with full aseptic technique using a 3 French needle (Cook Radial Catheterisation Set; Cook, Queensland, Australia) under local anaesthetic (1\% lignocaine; AstraZeneca, Sydney, Australia). The arterial cannula was attached to a pressure transducer (Biosensors International Pty Ltd, Singapore) and patency maintained with heparinised saline (Baxter, Toongambie, Australia). Blood pressure and heart rate were monitored throughout the study using a Dinamap automatic blood pressure recorder (Critikon Inc.)

Forearm blood flow was measured using the technique of venous occlusion plethysmography. A sealed, alloy-filled, double-stranded strain gauge was applied to the widest aspect of the forearm and attached to the plethysmograph (Medasonic, Mountain View, CA, USA). Venous outflow was occluded at the upper arm with a rapid cuff inflator (model E20; Hokanson Inc., Bellevue, WA, USA) at a pressure of $40-50 \mathrm{mmHg}$. The hand circulation was excluded with the use of a second cuff at the wrist inflated to suprasystolic levels. Forearm blood flow was measured at rest and during infusion of the endothelium vasodilator, acetylcholine (9.25, $18.5,37 \mu \mathrm{g} / \mathrm{min})$, the endothelium-independent vasodilator sodium nitroprusside $(2,4$ and $8 \mu \mathrm{g} / \mathrm{min})$ and the NO synthase inhibitor, $\mathrm{N}^{\mathrm{G}}$-monomethyl-L-arginine $(4 \mu \mathrm{mol} / \mathrm{min})$. This technique was carried out at the end of each of the two phases of milk consumption, that is, after weeks 12 and 24 .

\section{Determination of large artery properties}

Large-artery distensibility and aortic augmentation index were calculated from measured flow and pressure. Elevated pulse pressure is increasingly being recognised as a risk factor for cardiovascular, particularly coronary, disease (Dart \& Kingwell, 2001). Pulse pressure arises from the interaction of cardiac ejection (stroke volume) and the properties of the arterial circulation where an increased stiffness of the aorta and large arteries can lead to an increase in pulse pressure through a reduction in arterial compliance and effects on wave reflection. A number of factors are known to influence arterialwall behaviour, and dietary and lifestyle interventions have previously been shown to modify large-artery behaviour.

In the present study, a hand-held continuous-wave $3.5 \mathrm{MHz}$ Doppler transducer positioned in the suprasternal notch measured ascending aortic blood flow. Simultaneously, a surrogate pressure waveform representing the aortic root pressure was obtained via applanation tonometry of the proximal right carotid artery using a micro-tip (SPT-301) pencil-type transducer (Miller Instruments, Houston, TX, USA). Blood pressure and heart rate were determined using a Dinamap 1846 SP automatic blood pressure recorder (Critikon Inc.) at the brachial artery and brachial mean and diastolic pressures were used to calibrate the central pressure waveforms, as described previously (Cameron \& Dart, 1994). Aortic distensibility was determined from a modified two-element Windkessel model and augmentation index from the first zero crossing of the fourth derivative of the calibrated carotid pressure trace (Gatzka et al. 2001).

\section{Statistical analysis}

Data are given as means with their standard errors unless otherwise indicated. Repeated measures ANOVA followed by post hoc $t$ tests (SigmaStat Jandel) were applied on all data with $P<0.05$ set as the level of significance acceptance. The general linear model with repeated measures including order as a covariate (SPSS version 11.5; SPSS Inc., Chicago, IL, USA) was used to determine period-treatment interactions if any was indicated. Sample size ( $n$ 14) was determined on the parameter with the largest variance (in our hands), i.e. responses to acetylcholine (variance of $20 \%$ ), where we aimed to identify a delta of $25 \%$.

\section{Results}

\section{Lipid profile}

Total plasma cholesterol levels were significantly lower following 12 weeks of both the casein A1 and A2 interventions. The decrease was not different between casein A1 and A2 (see Table 4). Plasma LDL-cholesterol and HDL-cholesterol levels were significantly lower following 12 weeks of casein A1; there was a trend towards a similar decrease following 12 weeks of casein A2, although this did not achieve statistical significance. Neither HDL- nor LDL-cholesterol levels were different between the two interventions at 12 weeks. Plasma triacylglycerol levels were not altered by either casein A1 or A2.

\section{Common biochemical markers of disease}

Plasma insulin levels were not altered by either intervention. Plasma homocysteine levels were significantly lower following 12 weeks of casein A1; there was a trend towards a similar decrease following 12 weeks of casein A2, although this did not achieve statistical significance. Homocysteine levels were not different between the two interventions (at either 6 or 12 weeks). Plasma C-reactive protein, fibrinogen and von Willebrand levels were not altered by either intervention. Nor were collagen-binding assays. Protein $\mathrm{C}$ levels were significantly lower following 12 weeks of casein A1 and 6 weeks of casein A2; there was a trend towards a similar decrease following 12 weeks of casein A2, although this did not achieve statistical significance. Protein $\mathrm{C}$ levels were not different between the two interventions (at either 6 or 12 weeks). Protein $\mathrm{S}$ levels were 
Table 4. Plasma lipid profile, other commonly used markers of cardiovascular risk and supine resting blood pressure obtained at baseline (week 0 ) and after 6 and 12 weeks of $\beta$-casein A1 and after 6 and 12 weeks of $\beta$-casein A2†

(Mean values with their standard errors)

\begin{tabular}{|c|c|c|c|c|c|c|c|c|c|c|}
\hline & \multicolumn{6}{|c|}{$\beta$-Casein A1 } & \multicolumn{4}{|c|}{$\beta$-Casein A2 } \\
\hline & \multicolumn{2}{|c|}{ Baseline } & \multicolumn{2}{|c|}{6 weeks } & \multicolumn{2}{|c|}{12 weeks } & \multicolumn{2}{|c|}{6 weeks } & \multicolumn{2}{|c|}{12 weeks } \\
\hline & Mean & SEM & Mean & SEM & Mean & SEM & Mean & SEM & Mean & SEM \\
\hline Cholesterol (mmol/l) & $6 \cdot 3$ & 0.3 & $5 \cdot 9$ & 0.3 & $5 \cdot 6^{*}$ & 0.2 & $6 \cdot 2$ & 0.3 & $5 \cdot 7^{\star}$ & 0.3 \\
\hline LDL-cholesterol (mmol/l) & $3 \cdot 7$ & 0.2 & $3 \cdot 6$ & 0.2 & $3 \cdot 3^{*}$ & 0.2 & $3 \cdot 7$ & 0.2 & $3 \cdot 4$ & 0.2 \\
\hline HDL-cholesterol (mmol/l) & $1 \cdot 8$ & 0.2 & $1 \cdot 8$ & $0 \cdot 1$ & $1 \cdot 6^{*}$ & 0.1 & $1 \cdot 8$ & 0.2 & $1 \cdot 7$ & 0.2 \\
\hline Triacylglycerols (mmol/l) & 1.4 & $0 \cdot 2$ & $1 \cdot 2$ & 0.1 & $1 \cdot 4$ & 0.2 & 1.5 & 0.1 & $1 \cdot 3$ & 0.2 \\
\hline Insulin (mU/l) & $11 \cdot 8$ & $3 \cdot 6$ & $10 \cdot 1$ & $2 \cdot 3$ & $8 \cdot 8$ & $1 \cdot 3$ & $7 \cdot 8$ & $1 \cdot 2$ & $9 \cdot 0$ & $1 \cdot 3$ \\
\hline Homocysteine $(\mu \mathrm{mol} / \mathrm{l})$ & $9 \cdot 3$ & $0 \cdot 8$ & $9 \cdot 1$ & 0.7 & $8 \cdot 0^{*}$ & 0.5 & $8 \cdot 3$ & 0.6 & $8 \cdot 4$ & 0.5 \\
\hline C-reactive protein $(\mathrm{mg} / \mathrm{ml})$ & $4 \cdot 1$ & $0 \cdot 6$ & $3 \cdot 7$ & 0.3 & $3 \cdot 6$ & 0.4 & $3 \cdot 7$ & 0.3 & $4 \cdot 1$ & 0.5 \\
\hline Fibrinogen $(g / l)$ & 3.4 & 0.1 & 3.4 & 0.2 & $3 \cdot 3$ & 0.2 & 3.4 & 0.2 & $3 \cdot 1$ & 0.2 \\
\hline Von Willebrand's factor (\%) & $110 \cdot 9$ & $10 \cdot 5$ & $115 \cdot 4$ & $9 \cdot 0$ & $109 \cdot 9$ & $9 \cdot 7$ & $103 \cdot 5$ & $8 \cdot 3$ & $116 \cdot 5$ & 11.4 \\
\hline Collagen-binding assay (\%) & $110 \cdot 1$ & $10 \cdot 7$ & $117 \cdot 4$ & 8.4 & $101 \cdot 9$ & $6 \cdot 8$ & $105 \cdot 2$ & $6 \cdot 7$ & $105 \cdot 4$ & $7 \cdot 9$ \\
\hline Protein C (\%) & $114 \cdot 3$ & $5 \cdot 1$ & $109 \cdot 8$ & $5 \cdot 0$ & $107 \cdot 0^{*}$ & $5 \cdot 6$ & $107 \cdot 6^{*}$ & $5 \cdot 0$ & $107 \cdot 8^{\star}$ & $5 \cdot 2$ \\
\hline Protein S (\%) & $106 \cdot 3$ & $6 \cdot 1$ & $109 \cdot 2$ & $6 \cdot 4$ & $98 \cdot 2$ & $6 \cdot 0$ & $104 \cdot 5$ & $7 \cdot 8$ & $90 \cdot 0^{*}$ & $7 \cdot 4$ \\
\hline Systolic blood pressure (mmHg) & 127 & 4 & 131 & 4 & 131 & 4 & 127 & 4 & 131 & 5 \\
\hline Diastolic blood pressure $(\mathrm{mmHg})$ & 77 & 3 & 76 & 2 & 77 & 2 & 73 & 2 & 75 & 2 \\
\hline Mean arterial pressure $(\mathrm{mmHg})$ & 95 & 3 & 97 & 2 & 96 & 3 & 93 & 2 & 97 & 3 \\
\hline
\end{tabular}

* Mean value was significantly different from that at baseline $(P<0.05)$.

$\dagger$ Analysis was by repeated measures ANOVA followed by post hoc $t$ test when appropriate. Analysis by paired $t$ test A1 v. A2 at 6 weeks and also at 12 weeks demonstrated no significant difference between the two casein powders.

For details of subjects and procedures, see p. 137

significantly lower following 12 weeks of casein A2; there was a trend towards a similar decrease following 12 weeks of casein A1, although this did not achieve statistical significance. Protein $S$ levels were not different between the two interventions (at either 6 or 12 weeks).

\section{Blood pressure}

Mean systolic, diastolic and calculated mean arterial pressures (Table 4) did not differ with either A1 or A2 dietary supplementation.

\section{Forearm vascular reactivity studies (plethysmography)}

Both acetylcholine (Fig. 1) and sodium nitroprusside (Fig. 2) induced vasodilatory responses. The magnitude of these

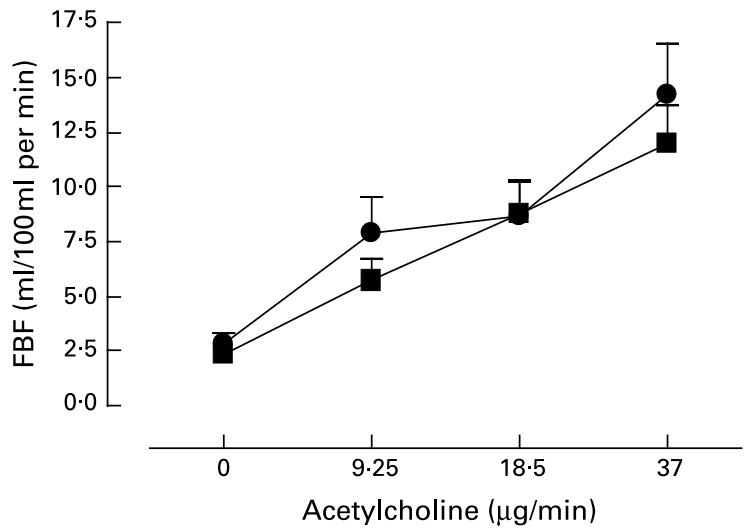

Fig. 1. Forearm blood flow (FBF) responses to acetylcholine. Responses did not differ between the groups treated with $\beta$-casein $A 1(-\mathbf{-}-)$ and $\beta$-casein A2 (-๑). For details of subjects and procedures, see p. 137. responses was not different between the two treatment groups. Multivariate analysis using the general linear model with repeated measures with order as a covariate was also performed to examine the effects of order on treatment (Table 5). There were no order-treatment interactions nor were there any carry-over effects. Vasoconstrictory responses to the NO synthase inhibitor, $\mathrm{N}^{\mathrm{G}}$-monomethyl-L-arginine were not different (results not shown) between the two groups.

\section{Aortic distensibility}

Aortic distensibility (Fig. 3 (a)), augmentation index (Fig. 3 (b)) and total peripheral resistance (Fig. 3 (c)) were not altered by either intervention. There was no order effect on distensibility (Table 4) or any of the arterial biomechanics indices (data not shown). It is unlikely that either supplementation had any effect on arterial biomechanics.

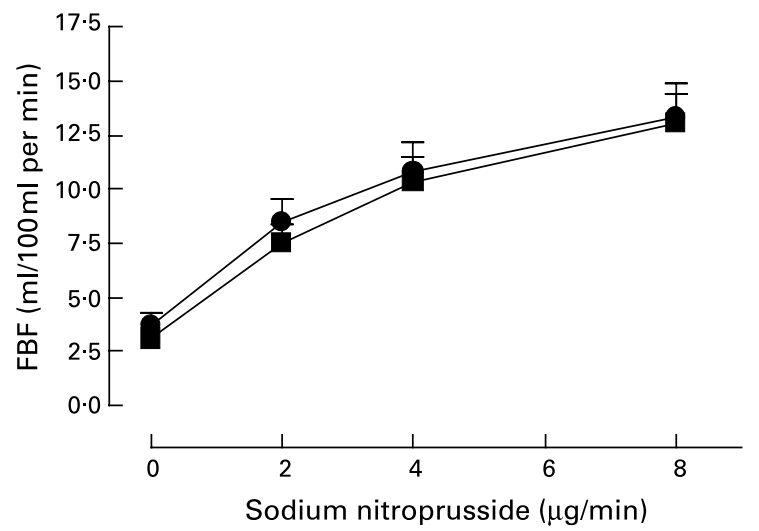

Fig. 2. Forearm blood flow (FBF) responses to sodium nitroprusside. Responses did not differ between the groups treated with $\beta$-casein A1 (- - -) and $\beta$-casein A2 (- -). For details of subjects and procedures, see p. 137. 
Table 5. Multivariate analysis to examine the existence of potential interactions between intervention ( $\beta$-casein $A 1$ or $\beta$-casein A2), dose (for acetylcholine and sodium nitroprusside), length of intervention (i.e. 6 or 12 weeks; for systemic arterial compliance) and order

\begin{tabular}{ll} 
& \\
& $P$ value \\
\hline Acetylcholine (basal + doses) & \\
Intervention (i.e. A1 v. A2) & 0.685 \\
Intervention $\times$ order & 0.486 \\
Dose & 0.018 \\
Intervention $\times$ dose & 0.721 \\
Intervention $\times$ dose $\times$ order & 0.844 \\
Sodium nitroprusside $($ basal + dose) & \\
Intervention (i.e. A1 v. A2) & 0.491 \\
Intervention $\times$ order & 0.613 \\
Dose & 0.002 \\
Intervention $\times$ dose & 0.891 \\
Intervention $\times$ dose $\times$ order & 0.824 \\
Aortic distensibility & \\
Intervention (i.e. A1 $v$. A2) & 0.386 \\
Intervention $\times$ order & 0.358 \\
Length of intervention (i.e. 6 v. 12 weeks) & 0.441 \\
Intervention $\times$ length of intervention & 0.279 \\
Intervention $\times$ length of intervention $\times$ order & 0.370 \\
\hline
\end{tabular}

${ }^{\star}$ For details of subjects and procedures, see p. 137.

\section{Discussion}

There is no evidence from the present study that supplementation with casein A1 has any cardiovascular health disadvantage over that with casein A2. Several markers of cardiovascular health were examined. These included plasma lipid profiles and inflammatory markers as well as measures of endothelium function and large arterial properties. None altered significantly following dietary supplementation with casein A1 when compared with casein A2.

Total plasma cholesterol levels were significantly decreased by the dairy shake dietary supplementation. This was regardless of whether the casein was of the A1 or A2 variety. This may reflect the changes introduced to the diets of the participants over the trial period, including minimising milk intake, and/or reflect an effect of the diary shakes themselves. The drop in total plasma cholesterol could be accounted for by both a fall in LDL- as well as HDL-cholesterol levels such that the plasma LDL:HDL ratio did not differ significantly (baseline LDL:HDL ratio 2.3 (SEM 0.2)) regardless of treatment (LDL:HDL ratio 2.2 (SEM 0.2) after both interventions. Hyperinsulinaemia (El-Atat et al. 2004) and hyperhomocysteinaemia (Lentz \& Haynes, 2004) are both associated with, and have been suggested to be predictors of, CVD. Neither casein A1 nor A2 supplementation altered plasma levels of either. Similarly, neither casein subtype altered plasma levels of Creactive protein, an acute-phase plasma protein, minor elevations of which are strongly associated with future cardiovascular events (Bassuk et al. 2004). The lack of effect of the dairy shakes intervention was also true of plasma levels of fibrinogen and von Willebrand factor. On the other hand, casein A2 was observed to significantly decrease plasma levels of proteins $\mathrm{S}$ and $\mathrm{C}$, while casein $\mathrm{A} 1$ affected only levels of protein $\mathrm{C}$. Both proteins $\mathrm{S}$ and $\mathrm{C}$ are anticoagulant proteins that play modulatory roles in blood coagulation. Protein $\mathrm{S}$ is of liver, endothelial and megakaryocyte origin; protein $\mathrm{C}$ is mainly of liver origin. Protein $\mathrm{S}$ has a demonstrable association with CHD (Dart et al. 1998). While it is tempting to extrapolate the finding that casein $\mathrm{A} 2$, but not $\mathrm{A} 1$, significantly decreases protein $\mathrm{S}$ and is thus suggestive of a cardioprotective effect, we would caution against such an interpretation since the protein $\mathrm{S}$ levels were in fact not significantly different in a direct comparison between 12 weeks of casein A1 v. casein A2.

Assessment of commonly used vascular functionality as surrogate measures of cardiovascular health were also assessed. These included assessing endothelium function in vivo using forearm vascular responses to the endotheliumdependent agonist acetylcholine. Endothelium-derived NO is a powerful anti-atherogenic mediator inhibiting events that promote atherosclerotic progression including vasoconstriction, monocyte adhesion, platelet aggregation and smooth muscle cell proliferation (Moncada, 1997). Diminished NO bioavailability is a hallmark of (early) atherosclerosis, which can be measured indirectly in patients as an impaired endothelium-dependent vasomotor response (Shaw et al. 2001). In this respect, endothelial vasodilator dysfunction has been demonstrated in subjects with established coronary risk factors even before the onset of morphological changes. Furthermore, many studies have indicated its reversibility after risk factor exclusion (Dart \& Chin-Dusting, 1999). More recently, the predictive value of endothelial vasodilator dysfunction for future cardiovascular events has been underscored by several research groups (Spieker et al. 2002; Bisoendial et al. 2003). In the present study, 12 weeks' supplementation with casein A2 had no influence over vascular responses to either acetylcholine or the direct smooth muscle dilator sodium nitroprusside.

Large arteries (for example, the proximal aorta) are now recognised to play a significant role in cardiovascular physiology beyond that of mere passive conduits. Their elasticity serves to buffer the pulsatile nature of cardiac function to facilitate diastolic tissue perfusion, of particular importance for the coronary circulation. In addition, a stiff large arterial circulation is a major factor in the genesis of systolic hypertension. Studies from our group have demonstrated the effect of a stiff circulation on the threshold for angina in patients with coronary disease, most probably a result of both decreased diastolic perfusion and elevated load on the left ventricle (Kingwell et al. 2002). Studies from others (Laurent et al. 2001, 2003; Boutouyrie et al. 2002) have demonstrated that elevated arterial stiffness (measured by pulse wave velocity) is a predictor of impaired survival in hypertensive patients and complements previous studies indicating the risk associated with elevated systolic and pulse blood pressure. Importantly we, and others, have demonstrated that whilst arterial stiffness is influenced by genetic factors (Benetos et al. 1995, 1996; Medley et al. 2003) and co-existent atherosclerosis (Gatzka et al. 1998; Waddell et al. 2001), a number of interventions can favourably influence large artery stiffness. These include aerobic exercise (Medley et al. 2003) and a number of nutritional or dietary interventions (Nestel et al. 1997, 1999a,b). These findings demonstrate that large artery biomechanical properties are modifiable and therefore potentially amenable to therapeutic interventions. In the present study, however, neither supplementation with casein AI nor A2 had any influence over measures of large arterial biomechanics. 

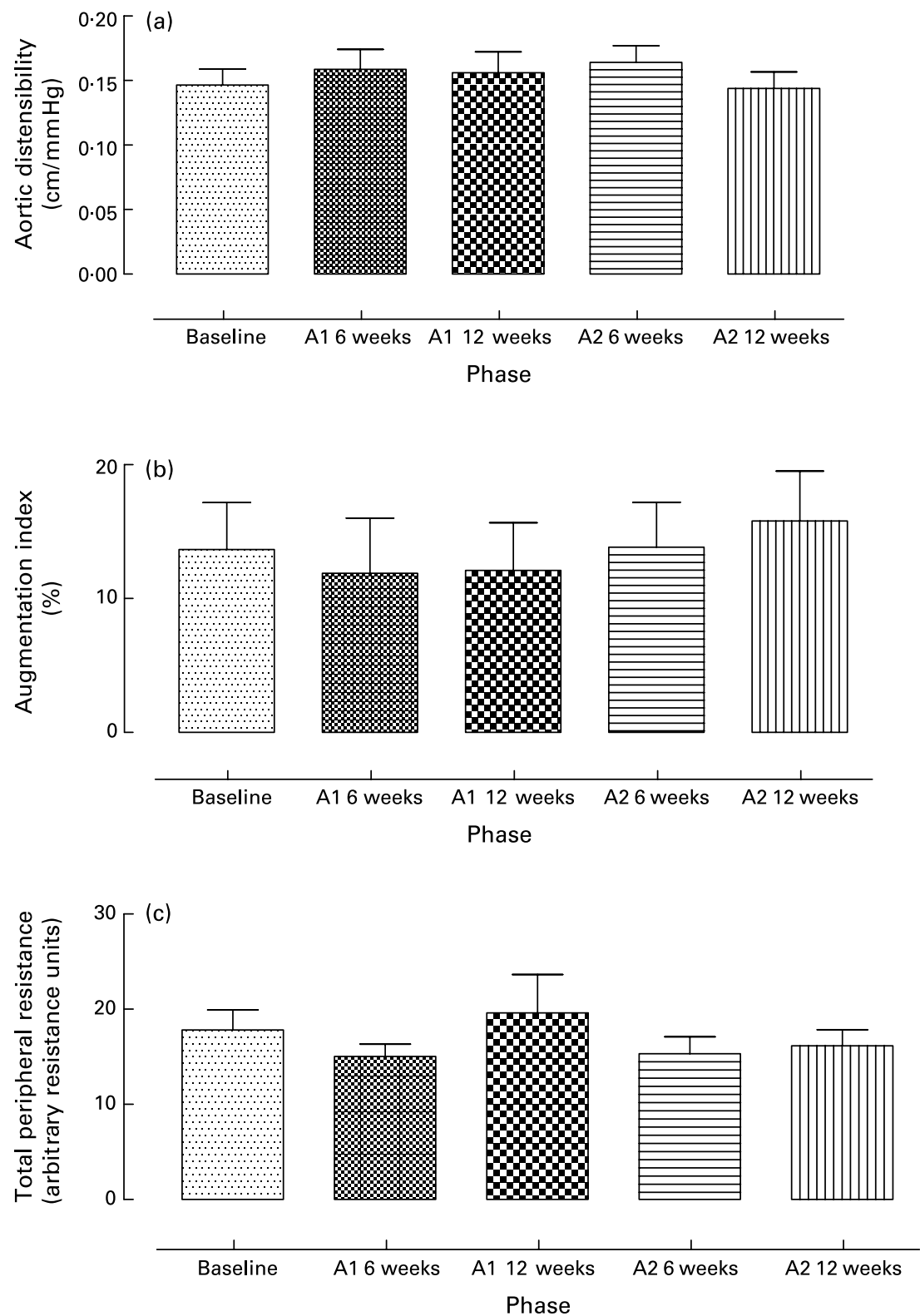

Fig. 3. Aortic distensibility (a), augmentation index (b) and total peripheral resistance (c) were not altered by either $\beta$-casein $A 1$ (A1) or $\beta$-casein $A 2$ (A2) supplementation. For details of subjects and procedures, see p. 137.

\section{Limitations of the study}

In the preparation of casein powder used there was some cross-contamination of casein A1 and A2, which may compromise the outcome. At its peak this was recorded to be no more than $20 \%$; in most samples, however, the cross-contamination was not observed. It is worth noting that the equivalent lifestyle to $100 \%$ purity is unlikely to be achievable given A1 is currently ubiquitous in almost all commercially available dairy products.

The present study included both females and males. It may well be that a cohort of males alone may have demonstrated a greater susceptibility to increased risk following A1 consumption, as has been shown for formula-fed male, but not female, infants with regard to increased antibodies against oxidised
LDL (Steinerova et al. 2004). The average age of the participants was 52 years with several over the age of 60 years. This should not, however, confound the results either in relation to vascular function (Lima et al. 2005) or arterial stiffness (Sugawara et al. 2004), as both have been demonstrated to be reversible in older-age subjects.

Another potential confounder is the lack of control over dietary intake and physical activity. However, given that the participants acted as their own controls and the present study aimed to examine the effect of casein A2 as a potential dietary modification against a backdrop of unchanged lifestyle habits, these and other lifestyle factors were not controlled for. It should also be noted that the habitual dairy intake for each participant was neither excessive nor abnormal and with the exception of such advice as given by the study dietitian as 
described, it is unlikely that this would have fluctuated enormously over the course of the study. A final potential confounder was the use of cocoa and citrus juice in some instances to enhance the palatability of the dairy shake. Indeed while the contents, for example, flavonoids, of both have been demonstrated to have their own beneficial effects, it is clear that these were not ingested in sufficient quantity in the present study to make a difference (interventions compared with baseline not different).

\section{Conclusion}

These data, taken together with the finding that supplementation with A2 or A1 had no significant effect on blood pressure, have led us to the conclusion that given as a dairy shake supplement, casein A2 has no cardioprotective advantage over casein A1.

\section{Acknowledgements}

The present study was supported by a grant from A2 Corporation Ltd, Auckland, New Zealand.

\section{References}

Bassuk SS, Rifai N \& Ridker PM (2004) High-sensitivity C-reactive protein: clinical importance. Curr Probl Cardiol 29, 439-493.

Benetos A, Gautier S, Ricard S, et al. (1996) Influence of angiotensinconverting enzyme and angiotensin II type 1 receptor gene polymorphisms on aortic stiffness in normotensive and hypertensive patients. Circulation 94, 698-703.

Benetos A, Topouchian J, Ricard S, Gautier S, Bonnardeaux A, Asmar R, Poirier O, Soubrier F, Safar M \& Cambien F (1995) Influence of angiotensin II type 1 receptor polymorphism on aortic stiffness in never-treated hypertensive patients. Hypertension 26, 44-47.

Bisoendial RJ, Hovingh GK, Levels JH, Lerch PG, Andresen I, Hayden MR, Kastelein JJ \& Stroes ES (2003) Restoration of endothelial function by increasing high-density lipoprotein in subjects with isolated low high-density lipoprotein. Circulation 107, 2944-2948.

Boutouyrie P, Tropeano AI, Asmar R, Gautier I, Benetos A, Lacolley P \& Laurent S (2002) Aortic stiffness is an independent predictor of primary coronary events in hypertensive patients: a longitudinal study. Hypertension 39, 10-15.

Cameron JD \& Dart AM (1994) Exercise training increases total systemic arterial compliance in humans. Am $J$ Physiol 266, H693-H701.

Dairy Australia (2005). www.dairyaustralia.com.au.

Dart AM \& Chin-Dusting JP (1999) Lipids and the endothelium. Cardiovasc Res 43, 308-322.

Dart AM, Cooper B, Kay SB \& Salem H (1998) Relationships between protein $\mathrm{C}$, protein $\mathrm{S}$, von Willebrand factor and euglobulin lysis time and cardiovascular risk factors in subjects with and without coronary heart disease. Atherosclerosis 140, 55-64.

Dart AM \& Kingwell B (2001) Pulse pressure - a review of mechanisms and clinical relevance. J Am Coll Cardiol 37, 975-984.

Davies DT \& Law AJR (1980) The content and composition of creamery milks in south-west Scotland. J Dairy Res 47, 83-90.

El-Atat FA, Stas SN, McFarlane SI \& Sowers JR (2004) Relationships between protein $\mathrm{C}$, protein $\mathrm{S}$, von Willebrand factor and euglobulin lysis time and cardiovascular risk factors in subjects with and without coronary heart disease. $J$ Am Soc Nephrol 15, $2816-2827$.

Gatzka CD, Cameron JD, Kingwell BA \& Dart AM (1998) Relation between coronary artery disease, aortic stiffness, and left ventricular structure in a population sample. Hypertension 32, 575-578.

Gatzka CD, Kingwell BA, Cameron JD, Berry KL, Liang YL, Dewar EM, Reid CM, Jennings GL \& Dart AM (2001) Gender differences in the timing of arterial wave reflection beyond differences in body height. J Hypertens 19, 2197-2203.

Kingwell BA, Waddell TK, Medley TL, Cameron JD \& Dart AM (2002) Large artery stiffness predicts ischemic threshold in patients with coronary artery disease. J Am Coll Cardiol 40, 773-779.

Laugesen M \& Elliott R (2003) Ischaemic heart disease, type 1 diabetes, and cow milk A1 $\beta$-casein. N Z Med J 116, U295.

Laurent S, Boutouyrie P, Asmar R, Gautier I, Laloux B, Guize L, Ducimetiere P \& Benetos A (2001) Aortic stiffness is an independent predictor of all-cause and cardiovascular mortality in hypertensive patients. Hypertension 37, 1236-1241.

Laurent S, Katsahian S, Fassot C, Tropeano AI, Gautier I, Laloux B \& Boutouyrie P (2003) Aortic stiffness is an independent predictor of fatal stroke in essential hypertension. Stroke 34, 1203-1206.

Lentz SR \& Haynes WG (2004) Homocysteine: is it a clinically important cardiovascular risk factor?" Cleve Clin J Med 71, 729-734.

Lima SM, Adrighi JM, Consolim-Colombo FM, Mansur Ade P, Rubira MC, Krieger EM \& Ramines JA (2005) Acute administration of $17 \beta$-oestradiol improves endothelin dependent vasodilatation in postmenopausal women. Maturitas 50, 266-274.

McLachlan CNS (2001) $\beta$-Casein $A^{1}$, ischaemic heart disease mortality, and other illness. Med Hypotheses 56, 262-272.

McLean DM, Graham ERB, Ponzoni RW \& McKenzie HA (1984) Effects of milk protein genetic milk variants on milk yield and composition. J Dairy Sci 51, 531-546.

Medley TL, Kingwell BA, Gatzka CD, Pillay P \& Cole TJ (2003) MMP-3 genotype contributes to age-related aortic stiffening through modulation of gene and protein expression. Circ Res 92, $1254-1261$

Menedez S, Centerio JA, Godinez R \& Rodriguez-Otero JL (2000) Effects of Lactobacillus strains on the ripening and organoleptic characteristics of Arzua-Ulloa cheese. Int J Food Microbiol 59, $37-46$.

Moncada S (1997) Nitric oxide in the vasculature: physiology and pathophysiology. Ann N Y Acad Sci 811, 60-67.

Ness AR, Davet Smith G \& Hart C (2001) Milk, coronary heart disease and mortality. J Epidemiology Commun Health 55, 379-392.

Nestel PJ, Pomeroy S, Kay S, Komesaroff P, Behrsing J, Cameron JD \& West L (1999a) Isoflavones from red clover improve systemic arterial compliance but not plasma lipids in menopausal women. J Clin Endocrinol Metab 84, 895-898.

Nestel PJ, Pomeroy S, Kay S, Komesaroff P, Behrsing J, Cameron JD \& West L (1999b) Isoflavones from red clover improve systemic arterial compliance but not plasma lipids in menopausal women. J Clin Endocrinol Metab 84, 3647.

Nestel PJ, Yamashita T, Sasahara T, Pomeroy S, Dart A, Komesaroff P, Owen A \& Abbey M (1997) Soy isoflavones improve systemic arterial compliance but not plasma lipids in menopausal and perimenopausal women. Arterioscler Thromb Vasc Biol 17, $3392-3398$.

Shaw JA, Chin-Dusting JP, Kingwell BA \& Dart AM (2001) Diurnal variation in endothelium-dependent vasodilatation is not apparent in coronary artery disease. Circulation 103, 806-812.

Spieker LE, Sudano I, Hurlimann D, Lerch PG, Lang MG, Binggeli C, Corti R, Ruschitzka F, Lüscher TF \& Noll G (2002) High-density lipoprotein restores endothelial function in hypercholesterolemic men. Circulation 105, 1399-1402.

Steinerova A, Korotvicka M, Racek J, Rajdl D, Trefil L, Stozicky F \& Rokyta Z (2004) Significant increase in antibodies against oxidized 
LDL particles (IgoxLDL) in three-month old infants who received milk formula (letter to editor). Atherosclerosis 173, $147-148$.

Sugawara J, Inoue H, Hayashi K, Yokoi T \& Kono I (2004) Effect of low intensity aerobic exercise training on arterial compliance in post-menopausal women. Hypertens Res 27, 897-901.

Tailford KA, Berry CL, Thomas AC \& Campbell JH (2003) A casein variant in cow's milk is atherogenic. Atherosclerosis 170, 13-19.
Waddell T, Dart A, Medley T, Cameron JD \& Kingwell BA (2001) Carotid pressure is a better predictor of coronary artery disease severity than brachial pressure. Hypertension 38, 927-931.

Yusuf S, Hawken S, Ônpuu S, Dans T, Avezum A, Lanas F, McQueen M, Budaj A, Pais P \& Varigos J (2004) Effect of potentially modifiable risk factors associated with myocardial infarction in 52 countries (the INTERHEART study): case-control study. Lancet 364, 937-952. 